\title{
Short communication: Effects of an immunomodulatory feed additive on phagocytic capacity of neutrophils and relative gene expression in circulating white blood cells of transition Holstein cows
}

\author{
Z. H. Wu, ${ }^{*}$ Y. Yu, ${ }^{*}$ † G. M. Alugongo, ${ }^{*}$ J. X. Xiao, ${ }^{*}$ J. H. Li, ${ }^{*}$ Y. X. Li, $†$ Y. J. Wang, ${ }^{*}$ S. L. Li, ${ }^{*}$ and Z. J. Cao ${ }^{* 1}$ \\ *State Key Laboratory of Animal Nutrition, College of Animal Science and Technology, China Agricultural University, Beijing 100193, China \\ †College of Animal Science and Technology, Henan University of Science and Technology, Luoyang, Henan, 471003, China
}

\begin{abstract}
High-producing dairy cows typically experience immunosuppression with dysregulated neutrophil function (e.g., compromised phagocytosis) during the transition period ( $3 \mathrm{wk}$ before to $3 \mathrm{wk}$ after parturition), which is causally associated with increased risk of infections. Enhanced neutrophil immune competence has significant bearing with the wellbeing of transition dairy cattle. In the current study, we investigated the effect of OmniGen-AF (OG; Phibro Animal Health, Quincy, IL) and its dose in modulation of neutrophil function of transition cows. Forty-eight multiparous cows were stratified by parity, somatic cell count, and expected calving date and randomly assigned to 3 treatments: OG fed at $0 \mathrm{~g} /$ head per day $(\mathrm{CON}), 60 \mathrm{~g} /$ head per day (OG60; recommended dose), and $90 \mathrm{~g} / \mathrm{head}$ per day (OG90; $1.5 \times$ recommended dose). The OG was added from dry off $(61.8 \pm 1.69 \mathrm{~d}$ before parturition) to $28 \mathrm{~d}$ in milk (DIM), and removed from all treatment groups at 29 to 35 DIM (the last week of the experimental period). Neutrophil phagocytic ability against Staphylococcus aureus and Escherichia coli was improved and tended to be improved, respectively, by OG from d 28 before parturition to 28 DIM. Cows in OG60 had higher neutrophil phagocytic ability against $S$. aureus and E. coli compared with CON cows from d 28 before parturition to 28 DIM. Neutrophil phagocytosis of $S$. aureus and E. coli was higher and tended to be higher for OG60 compared with CON on 35 DIM. The relative gene expression of $C X C L 8$ and $S E L L$ were upregulated and tended to be upregulated by OG from $60 \mathrm{~d}$ before parturition to 28 DIM; this was due to cows in OG60 having greater $S E L L$ and $C X C L 8$ gene expression than CON. Expression of $S E L L$ in circulating white blood cells of OG60-treated cows was greater than OG90 and
\end{abstract}

Received December 27, 2016.

Accepted May 24, 2017.

${ }^{1}$ Corresponding author: caozhijun@cau.edu.cn the relative expression of $C X C L 8$ gene tended to be greater for OG60 compared with CON on 35 DIM. In conclusion, feeding OG at the recommended dose of 60 $\mathrm{g} /$ head per day from dry off was effective in maintaining peripheral blood neutrophil function in transition dairy cows, and it is not necessary to feed OG beyond the recommended dose.

Key words: OmniGen-AF, neutrophil phagocytosis, $C X C L 8, S E L L$

\section{Short Communication}

It is common for high-producing dairy cows to experience immunosuppression during the transition period (3 wk before to 3 wk after parturition), which makes them more susceptible to opportunistic infections. As the first line of defense, neutrophils are crucial effector cells in immune surveillance and protection against invading pathogens (Burton and Erskine, 2003). Neutrophil trafficking, phagocytosis, and killing abilities are impaired by many of the physiological changes associated with parturition, which contributes to immunosuppression (Kulberg et al., 2002; Yuan et al., 2014). Diminished immunocompetence not only increases the number of new infections leading to disease, but may easily result in a subclinical disease developing into a clinical one (Kimura et al., 1999). Increased incidence of disease can be associated with reduction in milk yield and quality (Goff and Horst, 1997; Drackley, 1999).

Neutrophil phagocytic activity is crucial in prevention of animal diseases (Moya et al., 2008). To accomplish its mandate, the expression of adhesion molecules and cytokines is necessary. Whenever bacteria infect the body, the neutrophils need to egress the blood system and enter the infection sites with the aid of adhesion molecules and cytokines (Kimura et al., 1999). This is achieved by adhesion molecules binding and rolling along the endothelial cell surface of the vascular system (Kimura et al., 1999).

According to the manufacturer, OmniGen-AF (OG; Phibro Animal Health, Quincy, IL) contains mainly 
a mixture active dried Saccharomyces cerevisiae and B-complex vitamins and other trace compounds, such as plant proteins, diatomaceous earth, rice hulls, and mineral oil (Ryman et al., 2013; Brandão et al., 2016). OmniGen-AF is a widely used proprietary immunomodulator that has been proven to improve the neutrophil function in immunosuppressed sheep (Wang et al., 2007). A study on growing heifers also reported positive effect of OG on leukocyte function and gene expression (Ryman et al., 2013; Nace et al., 2014). Moreover, the study of Brandão et al. (2016) demonstrated that OG enhanced innate immunity parameters in an in vivo LPS challenge model. To the best of our knowledge, effects of OG dose on peripheral blood neutrophil phagocytosis and gene expression of multiparous transition Holstein cows has not been reported. We hypothesized that feeding OG beyond the normal recommended dose of $60 \mathrm{~g} /$ head per day would offer additional benefits to high-producing Holstein cows during the transition period by investigating its effect on the neutrophil phagocytic ability against Escherichia coli and Staphylococcus aureus and the gene expression of the adhesion molecule $S E L L$ and the cytokine $C X C L 8$.

Animal care and use were in accordance with practices outlined in the Guide for the Care and Use of Agricultural Animals in Research and Teaching (FASS, 2010). Forty-eight multiparous Holstein cows were stratified by parity, SCC, and expected calving date and assigned into 3 treatments ( 16 cows for each group: 9 cows in the third parity and 7 cows in the first parity): fed at $0 \mathrm{~g} /$ head per day $(\mathbf{C O N} ; \mathrm{SCC}=173.13 \pm 128.57 \times 1,000 /$ $\mathrm{mL}, \mathrm{BW}=723.87 \pm 86.51 \mathrm{~kg}, \mathrm{BCS}=3.43 \pm 0.26), 60$ $\mathrm{g} /$ head per day (recommended dose, OG60; SCC = $173.50 \pm 126.93 \times 1,000 / \mathrm{mL}, \mathrm{BW}=726.43 \pm 72.73$ $\mathrm{kg}, \mathrm{BCS}=3.46 \pm 0.29)$, and $90 \mathrm{~g} / \mathrm{head}$ per day $(1.5 \times$ recommended dose, OG90; $\mathrm{SCC}=174.56 \pm 139.16 \times$ $1,000 / \mathrm{mL}, \mathrm{BW}=729.07 \pm 67.84 \mathrm{~kg}, \mathrm{BCS}=3.50 \pm$ 0.28). Cows were transferred to an experimental barn $74 \mathrm{~d}$ before expected parturition and dried off $2 \mathrm{wk}$ later $(61.8 \pm 1.69 \mathrm{~d}$ before parturition $)$. The experimental barn was equipped with a delivery room, 48 feeding bunks, and the Roughage Intake Control System (Insentec B.V., Marknesse, the Netherlands). All the cows were trained to use the bunks before the start of the experiment. The experiment was conducted from dry off to 35 DIM. All cows were fed diets as a TMR, offered once (at $1600 \mathrm{~h}$ ) daily prepartum and twice (at 0730 and $1430 \mathrm{~h}$ ) postpartum. All the cows were milked 3 times daily (at 0700, 1400, and $2030 \mathrm{~h}$ ). The OG was mixed with corn meal before being added into a TMR mixer; the additive was added from dry off to 28 DIM.

Blood samples were collected (at $0800 \mathrm{~h}$ ) on $\mathrm{d}-60$, $-28,-14,-7,1,7,14,28,32$, and 35 , by puncturing the coccygeal vein with 20 gauge $\times 2.5 \mathrm{~cm}$ needles (all the collection days were relative to calving date). Blood sample $(10 \mathrm{~mL})$ used for neutrophil isolation was collected in $1 \mathrm{~K} 2$-EDTA vacuum tube (Shandong Aosaite Medical Devices Co. Ltd., Shandong, China) and a 3-mL blood sample used for RNA isolation was collected in 1 Tempus Blood RNA tube (Life Technologies, Foster City, CA) per cow. The Tempus Blood RNA tube was hand-shaken vigorously for $10 \mathrm{~s}$ after collection and stored at $-20^{\circ} \mathrm{C}$ until RNA isolation. The blood sample in K2-EDTA tube was sent to the laboratory for neutrophil isolation and phagocytosis ability (against $S$. aureus and E. coli) test.

Neutrophils were isolated from EDTA anticoagulated whole blood within $3 \mathrm{~h}$ of blood sampling using the Bovine Peripheral Blood Neutrophils Isolation Kit (Tianjin Haoyang Biological Manufacture Co. Ltd., Tianjin, China; catalog number: LZS1094). The density gradient separation method was used to isolate neutrophils from whole blood, as per Oh et al. (2008), with few modifications. A total of $9 \mathrm{~mL}$ of whole blood was blended with the same volume of blood diluent in the process of neutrophil isolation. After washing with Hank's Balanced Salt Solution (Yocon Biology Co. Ltd., Beijing, China) without $\mathrm{Ca}^{2+} / \mathrm{Mg}^{2+}$, the isolated neutrophil pellet was dissolved with $500 \mu \mathrm{L}$ of RPMI-1640 media (HyClone, Logan, UT) in a 1.5-mL centrifuge tube. A subsample $(10 \mu \mathrm{L})$ was taken and diluted with $90 \mu \mathrm{L}$ of PBS in a new $1.5-\mathrm{mL}$ centrifuge tube for cell counting. The final concentration of the suspension was adjusted to $3 \times 10^{\mathrm{E} 6}$ cells $/ \mathrm{mL}$ with RPMI-1640 media. Phagocytic activity was measured with pHrodo Green labeled $E$. coli or S. aureus BioParticles (Life Technologies). In brief, $2 \mathrm{~mL}$ of PBS was pipetted into a vial containing pHrodo Green labeled E. coli or S. aureus BioParticles. The solution was then briefly vortexed to completely suspend the particles. One milligram per milliliter (approximately $3 \times 10^{\mathrm{E} 8} \mathrm{E}$. coli or $S$. aureus particles per milliliter) of pHrodo Green E. coli or S. aureus BioParticles was obtained. Suspensions of PMNL $(200 \mu \mathrm{L})$ were placed into a $1.5-\mathrm{mL}$ sterile centrifuge tube with $10 \mu \mathrm{L}$ of $1 \mathrm{mg} / \mathrm{mL}$ pHrodo Green labeled E. coli or $S$. aureus BioParticles. The solution was briefly vortexed to mix the cells with BioParticles. The mixture was incubated for $30 \mathrm{~min}$ at $37^{\circ} \mathrm{C}$ and $100 \%$ humidity in a $5 \% \mathrm{CO}_{2}$ incubator. Two hundred microliters of FACS Fix (freshly made $4 \%$ paraformaldehyde in $1 \times$ PBS) was then added and placed at $4^{\circ} \mathrm{C}$ for $30 \mathrm{~min}$. The solution was centrifuged at $135 \times g$ at $4^{\circ} \mathrm{C}$ for $5 \mathrm{~min}$. The supernatant was removed and the cell pellet was resuspended in $50 \mu \mathrm{L}$ of $1 \times$ PBS. Finally, the phagocytosis ability was assessed by flow cytometry (488 $\mathrm{nm}$ of excitation with a 530/30-nm bandpass filter; BD LSRFortessa SORP, San Jose, CA). The rate of phagocytosis was calculated as the percentage of cells 
Table 1. Gene, sequence, amplicon size, and National Center for Biotechnology Information (NCBI) accession number of primers used to analyze gene expression by quantitative PCR

\begin{tabular}{|c|c|c|c|}
\hline Gene & $\begin{array}{l}\text { Primer sequence } \\
\text { forward }(\mathrm{F}) \text { and reverse }(\mathrm{R}) ; 5^{\prime}-3^{\prime}\end{array}$ & Amplicon size, bp & NCBI accession no. \\
\hline$C X C L 8$ & $\begin{array}{l}\text { F: AAGGAAAAGTGGGTGCAGAAG } \\
\text { R: ACCAGACCCACACAGTACATGAG }\end{array}$ & 184 & JN559767.1 \\
\hline$S E L L$ & $\begin{array}{l}\text { F: TCCTTCAAATCCCCTCATG } \\
\text { R: TTCCCGTGGTCTTGGTAGTC }\end{array}$ & 219 & NM_174182.1 \\
\hline$G A P D H$ & $\begin{array}{l}\text { F: TTGTGATGGGCGTGAACC } \\
\text { R: TCTTCTGGGTGGCAGTGATG }\end{array}$ & 168 & NM_001034034.2 \\
\hline
\end{tabular}

examined that showed any phagocytic activity after 30 min of incubation time (Karl et al., 1973).

The RNA was extracted from the blood in the Tempus Blood RNA tube. A 200- $\mu \mathrm{L}$ aliquot of whole blood was removed from the Tempus Blood RNA tube, mixed with $800 \mu \mathrm{L}$ of TRIzol reagent (Life Technologies) in a 1.5-mL centrifuge tube for lysis. One hundred sixty microliters of chloroform was added to the suspension and shaken for $15 \mathrm{~s}$, followed by incubation at room temperature for $5 \mathrm{~min}$. Subsequently, samples were centrifuged for $15 \mathrm{~min}$ at $12,000 \times g$ and $4^{\circ} \mathrm{C}$ and the upper phase was transferred to a new collection tube. Isometric isopropyl alcohol was added to the supernatant and the solution incubated at room temperature for $10 \mathrm{~min}$. Afterward, the solution was centrifuged at $12,000 \times g$ at $4^{\circ} \mathrm{C}$ for $10 \mathrm{~min}$, and the pellet was washed with $1 \mathrm{~mL}$ of $75 \%$ ethanol. To remove the genomic DNA, the extracted RNA was treated with gDNA Eraser in Prime Script RT reagent Kit (Takara Bio, Shiga, Japan) according to manufacturer's instructions. The RNA concentration and purity was measured with a NanoDrop ND-2000 spectrophotometer (Nanodrop Technologies, Wilmington, DE). Quality of RNA was assessed by testing the absorption (optical density at $260 / 280 \mathrm{~nm}$ ) ratios in a spectrophotometer.

Total RNA was stored at $-80^{\circ} \mathrm{C}$ for real-time reverse transcriptase PCR. The starting amount of RNA used for cDNA synthesis was $600 \mathrm{ng} / 20 \mu \mathrm{L}$. First-strand cDNA reaction was synthesized with Prime Script RT reagent Kit (Takara Bio) and the real-time PCR was carried out using the SYBR Premix Ex Taq (Takara Bio). All the operations were carried out according to the manufacturer's instructions. The gene-specific primers that were used for the evaluation of $S E L L$, $C X C L 8$, and endogenous control $(G A P D H)$ gene expression, were designed using Primer Premier 5.0 software (Premier Biosoft, Palo Alto, CA; Table 1). The $G A P D H$ was chosen as endogenous reference because it is stably expressed in various cells (Leutenegger et al., 2000). Each sample was analyzed in duplicate in 96-well plates and amplified in a Bio-Rad iCycler (BioRad Laboratories, Hercules, CA) by the amplification program (denaturation at $95^{\circ} \mathrm{C}$ for 5 min, followed by 40 cycles of $15 \mathrm{~s}$ at $95^{\circ} \mathrm{C}$ and $60 \mathrm{~s}$ at $56^{\circ} \mathrm{C}$ ). The final data were analyzed using the $2^{-\Delta \Delta C T}$ method, as described by Leutenegger et al. (2000). To assess the effect of OG supplementation on SELL and CXCL8 gene expression in peripheral blood in transition cows, differences in the cycle threshold $\left(\boldsymbol{C}_{\mathrm{T}}\right)$ value for $S E L L$ and $C X C L 8$ gene and the $C_{\mathrm{T}}$ value for the $G A P D H$ gene (endogenous control) were calculated as $\Delta C_{\mathrm{T}}$ value. Furthermore, $\Delta \Delta C_{\mathrm{T}}$ value was determined by subtracting the mean of $\Delta C_{\mathrm{T}}$ for CON samples (calibrator) from the $\Delta C_{\mathrm{T}}$ of each OG60 and OG90 samples. Finally, the relative gene expression, normalized to endogenous control and relative to the calibrator, was calculated by $2^{-\Delta \Delta C T}$.

Neutrophil phagocytosis of S. aureus and E. coli and the relative expression of $C X C L 8$ and $S E L L$ genes were analyzed using a mixed-effects model with repeated measures including treatment, time, and their interaction as fixed effects, and animal within treatment as a random effect for the whole experimental data $(-28$ to $28 \mathrm{~d}$ for neutrophil phagocytosis of $S$. aureus and $E$. coli, and -60 to $28 \mathrm{~d}$ for the relative expression of $C X C L 8$ and $S E L L$ gene, respectively). The lowest Bayesian information criterion (fit statistic) level was used to select covariance structure of the model for each parameter. Accordingly, first-order autoregressive covariance structure was selected. The model used was

$$
\mathrm{Y}_{\mathrm{ijk} l}=\mu+\mathrm{T}_{\mathrm{i}}+\mathrm{D}_{\mathrm{j}}+(\mathrm{T} \times \mathrm{D})_{\mathrm{ij}}+\mathrm{A}_{\mathrm{k}}\left(\mathrm{T}_{\mathrm{i}}\right)+\mathrm{e}_{\mathrm{ijkl}},
$$

where $Y_{\mathrm{ijkl}}$ is the dependent variable under examination, $\mu$ is the population mean for the variable, $T_{\mathrm{i}}$ is the fixed effect of treatment ( $\mathrm{i}=3$; CON, OG60, OG90), $D_{j}$ is the fixed effect of sampling day $(j=10 ;-60$, $-28,-14,-7,1,7,14,28,32,35 \mathrm{~d}),(\mathrm{T} \times \mathrm{D})_{\mathrm{ij}}$ is the fixed effect of interaction between treatment and time, $\mathrm{A}_{\mathrm{k}}\left(\mathrm{T}_{\mathrm{i}}\right)$ is the random effect of animal within treatment ( $\mathrm{k}=1$ to 16$)$, and $\mathrm{e}_{\mathrm{ijkl}}$ is the residual.

A generalized linear model including the effect of treatment for the data at each sampling point $[-60$ (CXCL8 and SELL gene expression), $-28,-14,-7,1$, $7,14,28,32,35 \mathrm{~d}]$. The model used was 


$$
\mathrm{Y}_{\mathrm{ij}}=\mu+\mathrm{T}_{\mathrm{i}}+\mathrm{e}_{\mathrm{ij}}
$$

where $Y_{i j}$ is the dependent variable under examination, $\mu$ is the population mean for the variable, $T_{i}$ is the fixed effect of treatment ( $\mathrm{i}=3$; CON, OG60, OG90), and $\mathrm{e}_{\mathrm{ij}}$ is the residual.

All statistical analyses were performed using SAS software (version 9.3; SAS Institute Inc., Cary, NC). For all statistical analyses, significance was declared at $P<0.05$ and trends at $0.05 \leq P \leq 0.10$, unless otherwise stated. The Fisher's protected least significant difference test was used for multiple treatment comparisons using the LSMEANS of SAS with letter grouping obtained using SAS pdmix800 macro (Saxton, 1998).

Neutrophil phagocytic ability against $E$. coli was affected by time $(P=0.035)$ and tended to be affected by treatment $(P=0.086)$ from $\mathrm{d} 28$ before parturition to 28 DIM; cows in OG60 had higher neutrophil phagocytic ability against $E$. coli compared with cows in $\operatorname{CON}(P=0.040$; Table 2$)$. We also detected a tendency for a treatment $\times$ time interaction on the phagocytosis of E. coli $(P=0.094$; Table 2). Treatment effects on neutrophil phagocytic ability against $E$. coli were detected on $\mathrm{d} 1$ and $7(P=0.030$ and $P=0.029$, respectively; Figure 1); specifically, phagocytosis of $E$. coli was higher on d 1 for OG60 compared with CON $(P=0.009)$ and on d 7 for OG90 and OG60 compared with CON $(P=0.013$ and $P=0.047$, respectively; Figure 1). Moreover, OG60 tended to have higher neutrophil phagocytic ability against $E$. coli than CON on d $35(P=0.094$; Figure 1$)$. Neutrophil phagocytic ability against $S$. aureus was affected by treatment and time ( $P=0.036$ and $P=0.017$, respectively) from $\mathrm{d}$ 28 before parturition to 28 DIM, such that OG60 had higher neutrophil phagocytic ability against $S$. aureus than $\operatorname{CON}(P=0.011$; Table 2$)$. We found an effect of treatment on phagocytosis of $S$. aureus on d $1(P=$ 0.012), with OG60 having a higher neutrophil phagocytic ability against $S$. aureus than $\mathrm{CON}$ and OG90 $(P=0.003$ and $P=0.037$, respectively; Figure 1$)$. Al- though neutrophil phagocytic ability against $S$. aureus were similar between CON and OG treatments on d 35, CON had lower neutrophil phagocytic ability against $S$. aureus compared with OG60 $(P=0.043$; Figure 1).

We detected an association of treatment on the relative expression of $C X C L 8(P=0.031)$ from d 60 before parturition to $28 \mathrm{DIM}$. In the same period, the relative expression of $C X C L 8$ was greater for OG60 compared with that of CON ( $P=0.009$; Table 2$)$. Overall, CON had similar $C X C L 8$ gene expression to OG90 on individual sampling days, but lower than OG60 on d -14 and $35(P=0.049$ and $P=0.067$, respectively; Figure $2)$. The relative expression of $S E L L$ was affected by time $(P=0.001)$, and we noted a tendency of treatment effects $(P=0.095)$ from d 60 before parturition to 28 DIM, with OG60 having a greater SELL gene expression than CON ( $P=0.033$; Table 2$)$. We detected tendencies for effect of treatment on the relative expression of $S E L L$ on d -14 and $35(P=0.079$ and $P=$ 0.093 , respectively; Figure 2). Gene expression of $S E L L$ was greater for OG60 compared with CON on d -14 $(P=0.025)$ and when compared with OG90 on d $35(P$ $=0.031$; Figure 2$)$. In addition, $S E L L$ gene expression was similar between CON and OG treatments on $\mathrm{d}-7$, but OG60 tended to have greater relative expression of $S E L L$ than CON $(P=0.066$; Figure 2$)$.

Neutrophils are of great importance in the containment of infection, as they can destroy bacteria with a broad array of mechanisms (Burvenich et al., 2007). Phagocytosis by neutrophils is the most effective defense mechanism against bacterial infection (Paape et al., 2002). In response to infections, such as mastitis, neutrophils migrate directly from the blood into the bacterial hoard to phagocytize and kill the bacteria (Paape et al., 2002). In our study, neutrophil phagocytic ability against $E$. coli and $S$. aureus, the 2 most virulent mastitis-causing bacteria (Burvenich et al., 2007), was enhanced by OG supplementation (7 cows were treated for clinical mastitis in $\mathrm{CON}$, whereas 3 cows in OG60 and 2 cows in OG90 received treatment, $P=0.01$; data not presented). We hypothesized that

Table 2. Effect of OmniGen-AF (OG; Phibro Animal Health, Quincy, IL) supplementation on neutrophil phagocytic ability (against Staphylococcus aureus and Escherichia coli) and the relative expression of CXCL8 and SELL genes in transition Holstein cows from 28 d before parturition to 28 DIM and from $60 \mathrm{~d}$ before parturition to 28 DIM

\begin{tabular}{|c|c|c|c|c|c|c|c|}
\hline \multirow[b]{2}{*}{ Item } & \multicolumn{3}{|c|}{ Treatment $^{1}$} & \multirow[b]{2}{*}{ SEM } & \multicolumn{3}{|c|}{$P$-value } \\
\hline & $\mathrm{CON}$ & OG60 & OG90 & & Treatment & Time & Treatment $\times$ time \\
\hline CXCL8 & $1.17^{\mathrm{b}}$ & $1.48^{\mathrm{a}}$ & $1.32^{\mathrm{ab}}$ & 0.079 & 0.031 & 0.168 & 0.929 \\
\hline SELL & $1.07^{\mathrm{b}}$ & $1.21^{\mathrm{a}}$ & $1.16^{\mathrm{ab}}$ & 0.045 & 0.095 & 0.001 & 0.387 \\
\hline
\end{tabular}

$\overline{\mathrm{a}, \mathrm{b}}$ Least squares means within a row with different superscripts differ $(P<0.05)$.

${ }^{1} \mathrm{CON}=\mathrm{OG}$ was fed at $0 \mathrm{~g} /$ head per day; OG60 $=\mathrm{OG}$ was fed at $60 \mathrm{~g} /$ head per day; OG90 $=\mathrm{OG}$ was fed at $90 \mathrm{~g} / \mathrm{head}$ per day. 
the enhanced neutrophil phagocytic ability might be achieved by vitamin $\mathrm{B}$, especially vitamin $\mathrm{B}_{12}$ and folic acid, in OG. Vitamin $\mathrm{B}_{12}$ and folic acid might activate the hexose monophosphate shunt, which is associated with neutrophil phagocytic ability (Kaplan and Basford, 1976; Youinou et al., 1982). Moreover, the yeast component in the supplement contains molecules, such
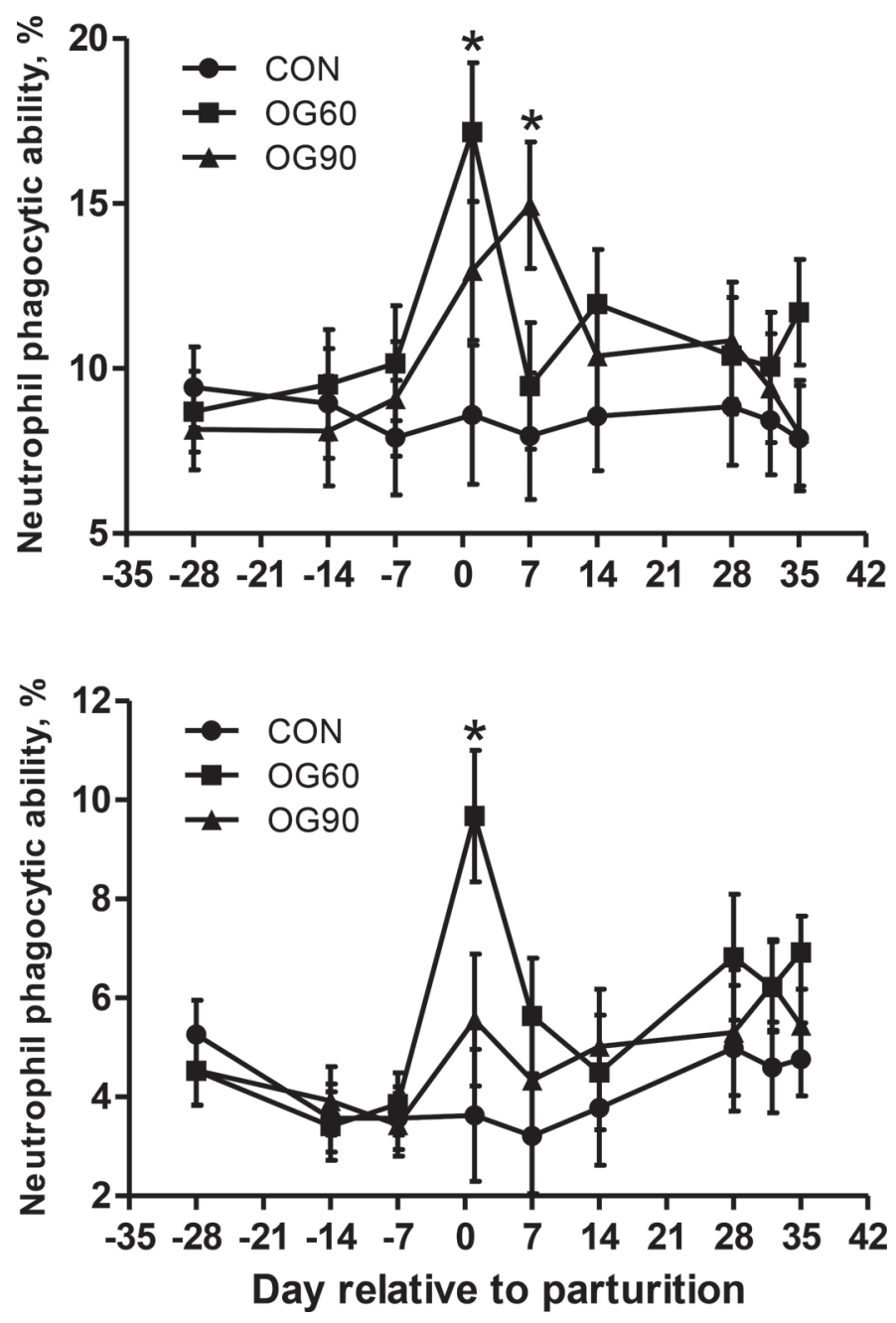

Figure 1. Neutrophil phagocytic ability [against Escherichia coli (top) and Staphylococcus aureus (bottom)] of multiparous transition cows fed OmniGen-AF (OG; Phibro Animal Health, Quincy, IL) at $0 \mathrm{~g} /$ head per day (CON; $\mathrm{n}=16$ ), $60 \mathrm{~g} /$ head per day (OG60; recommended dose; $\mathrm{n}=16$ ), or $90 \mathrm{~g} /$ head per day (OG90; $1.5 \times$ recommended dose; $\mathrm{n}=16$ ) from $28 \mathrm{~d}$ before parturition to 28 DIM. The neutrophil phagocytic ability refers to the percentage of cells examined that showed any phagocytic activity after 30 min of incubation time. Error bars represent SEM. Phagocytosis of E. coli was higher on d 1 for OG60 compared with CON $(P=0.009)$ and on d 7 for OG90 and OG60 compared with CON ( $P=0.013$ and $P=0.047$, respectively); neutrophil phagocytic ability against $S$. aureus was higher for OG60 compared with CON and OG90 $(P=0.003$ and $P=0.037)$ on $\mathrm{d} 1$; OG60 had higher and tended to have higher neutrophil phagocytic ability against $S$. aureus and $E$. coli than CON on d $35(P=0.043$ and $P=0.094$, respectively). ${ }^{*} P<0.05$. as mannans, mannoproteins, and zymosan, which may also correlate with phagocytosis (Aderem and Ulevitch, 2000). Whereas the mechanisms that neutrophil phagocytic capacity were enhanced by OG should be validated in future research. The OG60 group had the greatest neutrophil phagocytic ability compared with the CON group from d 28 before parturition to 28 DIM; these results are consistent with those of Ryman et al. (2013) and Nace et al. (2014), who demonstrated that neutrophil phagocytosis of E. coli and $S$. aureus was better in cows supplemented with OG. Neutrophil phagocytosis in treatment groups increased immediately after parturition. It is plausible that cows fed OG
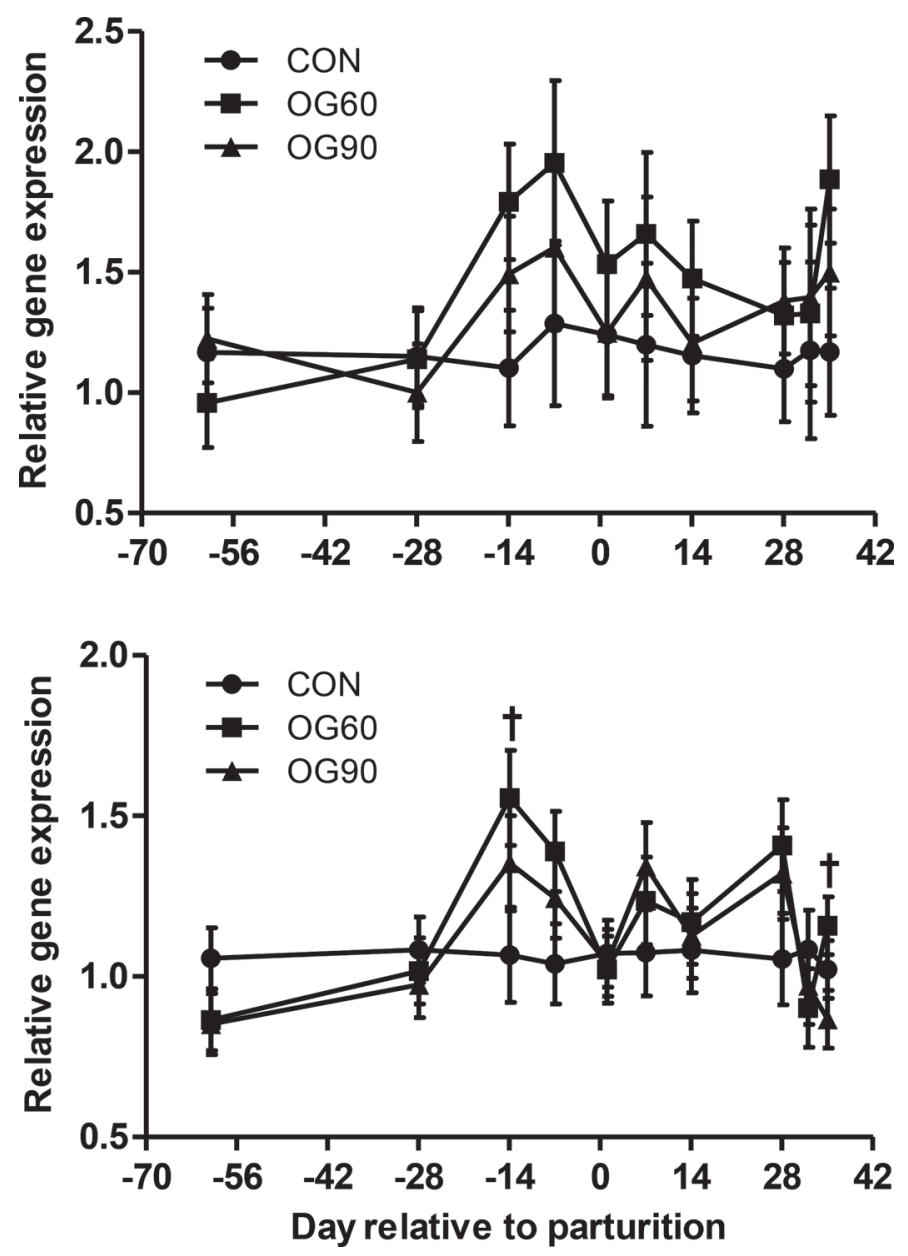

Figure 2. Relative expression of $C X C L 8$ (top) and $S E L L$ (bottom) genes of multiparous transition cows fed OmniGen-AF (OG; Phibro Animal Health, Quincy, IL) at $0 \mathrm{~g} /$ head per day $(\mathrm{CON} ; \mathrm{n}=16), 60$ $\mathrm{g} /$ head per day (OG60; recommended dose; $\mathrm{n}=16$ ), or $90 \mathrm{~g} /$ head per day (OG90; $1.5 \times$ recommended dose; $\mathrm{n}=16$ ) from $60 \mathrm{~d}$ before parturition to 28 DIM. Error bars represent SEM. CON had lower $C X C L 8$ gene expression than OG60 on $\mathrm{d}-14$ and $35(P=0.049$ and $P=0.067$, respectively); SELL gene expression was greater for OG60 compared with $\mathrm{CON}$ on $\mathrm{d}-14(P=0.025)$ and when compared with OG90 on d $35(P=0.031)$; OG60 tended to have greater $S E L L$ gene expression than CON $(P=0.066)$ on $d-7$. $\dagger 0.05<P<0.1$. 
had an increased ability to launch a disease defense mechanism when they are exposed to pathogens. Furthermore, phagocytosis of $E$. coli and $S$. aureus in OG60 group was still more effective on d 35 compared with CON. This implies that, although withdrawal of OG might have made some fluctuations on the phagocytic ability of neutrophils, the neutrophil phagocytic ability of cows in OG60 was still augmented 1 wk later. Thus, feeding $\mathrm{OG}$ by the recommended dose $(60 \mathrm{~g} / \mathrm{head}$ per day) had sustained effects on the immunocompetence of the transition cows over and beyond the time of supplementation, at least for a short period.

The SELL gene is a transmembrane cell adhesion molecule, which expressed on the surface of most circulating leukocytes can regulate leucocyte recruitment to acute and chronic inflammation site (Ivetic, 2013). Expression of $C X C L 8$ occurs via various types of cells and exerts a variety of functions on leukocytes, especially on neutrophils, upon stimulation with inflammatory stimuli (Harada et al., 1994). Paape et al. (2002) reported that the mammary gland can only be protected from bacterial invasion when neutrophils rapidly move into the infected area resulting in phagocytosis and killing of the bacteria. The SELL gene, as the primary adhesion molecule on the surface of neutrophils, is essential for their migration into an infection site, and its gene expression is considered as constitutive (Weber et al., 2001). On the other hand, cytokine $C X C L 8$, released during an infection, is a critical factor in activating neutrophils and enhancing phagocytosis (Leutenegger et al., 2000; Ryman et al., 2013). Furthermore, it acts as an important mediator in recruiting neutrophils to inflammation sites (Fonseca et al., 2009). In the present study, the relative expression of $C X C L 8$ and $S E L L$ were enhanced by OG. The mechanism by which OG supplementation enhances $C X C L 8$ and SELL gene expression is unknown; however, the natural products of yeast and fungal organisms in OG, such as fungal oligosaccharides and zymosan, act as pathogen-associated motifs, which interact with toll-like receptors (TLR), especially TLR2 and TLR-4, which may lead to the activation of gene expression associated with innate immunity (Aderem and Ulevitch, 2000; Wang et al., 2007). Hence, we speculated that the supplement interacts with TLR in the intestinal epithelial cells and eventually leads to the upregulation of $C X C L 8$ and $S E L L$ in a series of reactions. The OG60 group posted greater CXCL8 and SELL gene expression than CON. The results were similar to a study of Ryman et al. (2013), in which SELL mRNA expression on blood leukocytes was increased by OG supplementation; however, those authors did not find differences in $C X C L 8$ gene expression, potentially due to the parity effect. Viability of neutrophils in blood of primiparous cows has been shown to be usually higher
(Mehrzad et al., 2002), which could be the case in the Ryman et al. (2013) study, which used heifers only. The upregulation of $C X C L 8$ in our study might be a compensation to the relatively lower neutrophil viability in multiparous cows. The relative expression of $S E L L$ and $C X C L 8$ in OG60 and OG90 decreased on d 1 and 14. The decrease could be attributed to the calving stress and change in the milking parlor on these days, respectively. Our cows were milked in a smaller milk parlor (Double 8, BouMatic, Madison, WI) in the first week of lactation, which is closer to the experimental pen. From d 8 postcalving, cows were milked in the main milking parlor (Double 48, BouMatic), which is around $280 \mathrm{~m}$ from the experimental pen. Some studies found that a novel milking environment might be a stressor to cows (Sutherland et al., 2012; Sutherland and Tops, 2014). Fluctuations were also observed in the last week, which could be as a result of the withdrawal of OG and the changes in social organization within the group, as some cows were removed after they finished the experiment.

Not only the neutrophil phagocytosis and gene expression on blood leukocytes were improved by OG supplementation, but the fatty acid concentration tended to be reduced by OG $(P=0.083$; data not presented), and cows in CON had higher BHB concentration than OG90 $(P<0.05$; data not presented). Excess fatty acids and BHB result in fatty liver and ketosis and have negative effects on immune function of earlylactating cows (Esposito et al., 2014).

In conclusion, feeding OG from dry off was effective in improving neutrophil phagocytosis of $E$. coli and $S$. aureus and the expression of CXCL8 and SELL by white blood cells in multiparous transition dairy cows. Feeding OG beyond the recommended dose $(60 \mathrm{~g} /$ head/d) is not necessary. Furthermore, we observed the sustained immunomodulatory effect of feeding OG at recommended dose at $1 \mathrm{wk}$ after cessation of supplementation.

\section{ACKNOWLEDGMENTS}

The authors thank Longfeng Zhang and $\mathrm{Na} \mathrm{Lu} \mathrm{of}$ China Agricultural University for their assistance with laboratory work; Zhonglin Fu from the National Center for Protein Sciences Beijing (Peking University, Beijing, China) for his assistance with the FACS. The authors also acknowledge the staff of Sino Farm (Beijing, China) for their assistance with animal experiment.

\section{REFERENCES}

Aderem, A., and R. J. Ulevitch. 2000. Toll-like receptors in the induction of the innate immune response. Nature 406:782-787. 
Brandão, A. P., R. F. Cooke, F. N. Corra, M. B. Piccolo, R. Gennari, T. Leiva, and J. L. M. Vasconcelos. 2016. Physiologic, health, and production responses of dairy cows supplemented with an immunomodulatory feed ingredient during the transition period. J. Dairy Sci. 99:5562-5572.

Burton, J. L., and R. J. Erskine. 2003. Immunity and mastitis. Some new ideas for an old disease. Vet. Clin. North Am. Food Anim. Pract. 19:1-45.

Burvenich, C., D. D. Bannerman, J. D. Lippolis, L. Peelman, B. J. Nonnecke, M. E. Kehrli, and M. J. Paape. 2007. Cumulative physiological events influence the inflammatory response of the bovine udder to Escherichia coli infections during the transition period. J. Dairy Sci. 90(Suppl.):E39-E54.

Drackley, J. K. 1999. Biology of dairy cows during the transition period: The final frontier? J. Dairy Sci. 82:2259-2273.

Esposito, G., P. C. Irons, E. C. Webb, and A. Chapwanya. 2014. Interactions between negative energy balance, metabolic diseases, uterine health and immune response in transition dairy cows. Anim. Reprod. Sci. 144:60-71.

FASS. 2010. Guide for the Care and Use of Agricultural Animals in Research and Teaching. 3rd ed. FASS, Champaign, IL.

Fonseca, I., P. V. Silva, C. C. Lange, M. F. M. Guimaraes, M. Weller, K. R. S. Sousa, P. S. Lopes, J. D. Guimaraes, and S. E. F. Guimaraes. 2009. Expression profile of genes associated with mastitis in dairy cattle. Genet. Mol. Biol. 32:776-781.

Goff, J. P., and R. L. Horst. 1997. Physiological changes at parturition and their relationship to metabolic disorders. J. Dairy Sci. 80:1260-1268.

Harada, A., N. Sekido, T. Akahoshi, T. Wada, N. Mukaida, and K. Matsushima. 1994. Essential involvement of interleukin-8 (IL-8) in acute inflammation. J. Leukoc. Biol. 56:559-564.

Ivetic, A. 2013. Signals regulating L-selectin-dependent leucocyte adhesion and transmigration. Int. J. Biochem. Cell Biol. 45:550-555.

Kaplan, S. S., and R. E. Basford. 1976. Effect of vitamin B12 and folic acid deficiencies on neutrophil function. Blood 47:801-805.

Karl, L., M. Chvapil, and C. F. Zukoski. 1973. Effect of zinc on the viability and phagocytic capacity of peritoneal macrophages. Proc. Soc. Exp. Biol. Med. 142:1123-1127.

Kimura, K., J. P. Goff, and M. E. Kehrli Jr. 1999. Effects of the presence of the mammary gland on expression of neutrophil adhesion molecules and myeloperoxidase activity in periparturient dairy cows. J. Dairy Sci. 82:2385-2392.

Kulberg, S., A. K. Storset, B. Heringstad, and H. J. S. Larsen. 2002. Reduced levels of total leukocytes and neutrophils in Norwegian cattle selected for decreased mastitis incidence. J. Dairy Sci. 85:3470-3475.

Leutenegger, C. M., A. M. Alluwaimi, W. L. Smith, L. Perani, and J. S. Cullor. 2000. Quantitation of bovine cytokine mRNA in milk cells of healthy cattle by real-time TaqMan polymerase chain reaction. Vet. Immunol. Immunopathol. 77:275-287.

Moya, S. L., M. Alonso Gómez, L. A. Boyle, J. F. Mee, B. O'Brien, and S. Arkins. 2008. Effects of milking frequency on phagocyto- sis and oxidative burst activity of phagocytes from primiparous and multiparous dairy cows during early lactation. J. Dairy Sci. 91:587-595.

Mehrzad, J., L. Duchateau, S. Pyörälä, and C. Burvenich. 2002. Blood and milk neutrophil chemiluminescence and viability in primiparous and pluriparous dairy cows during late pregnancy, around parturition and early lactation. J. Dairy Sci. 85:3268-3276.

Nace, E. L., S. C. Nickerson, F. M. Kautz, S. Breidling, D. Wochele, L. O. Ely, and D. J. Hurley. 2014. Modulation of innate immune function and phenotype in bred dairy heifers during the periparturient period induced by feeding an immunostimulant for 60 days prior to delivery. Vet. Immunol. Immunopathol. 161:240-250.

Oh, H., B. Siano, and S. Diamond. 2008. Neutrophil isolation protocol. J. Vis. Exp. 17:e745.

Paape, M., J. Mehrzad, X. Zhao, J. Detilleux, and C. Burvenich. 2002. Defense of the bovine mammary gland by polymorphonuclear neutrophil leukocytes. J. Mammary Gland Biol. Neoplasia 7:109-121.

Ryman, V. E., S. C. Nickerson, F. M. Kautz, D. J. Hurley, L. O. Ely, Y. Q. Wang, and N. E. Forsberg. 2013. Effect of dietary supplementation on the antimicrobial activity of blood leukocytes isolated from Holstein heifers. Res. Vet. Sci. 95:969-974.

Saxton, A. M. 1998. A macro for converting mean separation output to letter groupings in proc mixed. Pages 1243-1246 in Proc. 23rd SAS User Group Intl. SAS Institute, Cary, NC.

Sutherland, M. A., A. R. Rogers, and G. A. Verkerk. 2012. The effect of temperament and responsiveness towards humans on the behavior, physiology and milk production of multi-parous dairy cows in a familiar and novel milking environment. Physiol. Behav. 107:329-337.

Sutherland, M. A., and M. Tops. 2014. Possible involvement of oxytocin in modulating the stress response in lactating dairy cows. Front. Psychol. 5:951.

Wang, Y., S. B. Puntenney, J. L. Burton, and N. E. Forsberg. 2007. Ability of a commercial feed additive to modulate expression of innate immunity in sheep immunosuppressed with dexamethasone. Animal 1:945-951.

Weber, P. S., S. A. Madsen, G. W. Smith, J. J. Ireland, and J. L. Burton. 2001. Pre-translational regulation of neutrophil L-selectin in glucocorticoid-challenged cattle. Vet. Immunol. Immunopathol. 83:213-240.

Youinou, P. Y., M. A. Garre, J. F. Menez, J. M. Boles, J. F. Morin, Y. Pennec, P. J. Miossec, P. P. Morin, and G. L. Menn. 1982 Folic acid deficiency and neutrophil dysfunction. Am. J. Med. 73:652-657.

Yuan, K., C. F. Vargas-Rodriguez, L. K. Mamedova, M. B. Muckey, M. A. Vaughn, D. D. Burnett, J. M. Gonzalez, E. C. Titgemeyer, K. E. Griswold, and B. J. Bradford. 2014. Effects of supplemental chromium propionate and rumen-protected amino acids on nutrient metabolism, neutrophil activation, and adipocyte size in dairy cows during peak lactation. J. Dairy Sci. 97:3822-3831. 